\title{
PEMBUATAN EDIBLE FILM ANTIBAKTERI BERBAHAN DASAR PEKTIN ALBEDO SEMANGKA, SAGU, DAN EKSTRAK BAWANG PUTIH
}

\author{
Fitria Yulistiani1 $^{1, *}$, Dianty Rosirda Dewi Kurnia ${ }^{1}$, Miranti Agustina ${ }^{1}$, \\ Yaumi Istiqlaliyah ${ }^{1}$ \\ ${ }^{1}$ Jurusan Teknik Kimia, Politeknik Negeri Bandung \\ Jln. Gegerkalong Hilir, Ds. Ciwaruga, Bandung 40012 \\ *Email: fitria.yulistiani@polban.ac.id
}

\begin{abstract}
ABSTRAK
Edible film berbahan dasar pati memiliki kelemahan pada sifat kuat tarik, elastisitas, dan kemampuan antimikroba. Sifat-sifat tersebut dapat ditingkatkan dengan menambahkan pektin, pemlastis, dan aditif. Penelitian ini dilakukan untuk mengkaji pembuatan edible film dari pektin albedo semangka dengan penambahan sorbitol dan gliserol sebagai bahan pemlastis, tepung sagu sebagai tambahan sumber pektin, dan ekstrak bawang putih sebagai aditif antimikroba. Variasi yang dilakukan adalah penambahan ekstrak bawang putih $(0 \% ; 2,5 \% ; 5 \% ; 7,5 \% ; 10 \%)$ dan jenis pemlastis (gliserol dan sorbitol). Karakteristik yang diamati meliputi kuat tarik, perpanjangan, dan zona hambat bakteri. Edible film dengan karakteristik terbaik yaitu kuat tarik $366,4 \mathrm{~kg} / / \mathrm{cm}^{2}$, perpanjangan $35,4 \%$, dan zona hambat bakteri $16,5 \mathrm{~mm}$ (metode sumuran) adalah sampel dengan konsentrasi ekstrak bawang putih $10 \%$ dan pemlastis gliserol.
\end{abstract}

Kata kunci: Albedo semangka, antimikroba, edible film, ekstrak bawang putih, plasticizer

\begin{abstract}
Starch based edible films have weaknesses in tensile strength, elasticity and anti-microbial ability. These properties can be improved by adding pectin, plasticizer, and additives. This research purposed to study edible film production using pectin from watermelon albedo with glycerol and sorbitol as plasticizer, sago starch as additional pectin source, and garlic extract as antimicrobial additive. Garlic extract is variated between 0 to $10 \%$ while plasticizer is variated between glycerol and sorbitol. The observed characteristics include tensile strength, elongation, and bacterial inhibition zone. Edible films with the best characteristics, tensile strength of $366.4 \mathrm{~kg} / \mathrm{cm}^{2}$, elongation of $35.4 \%$ and bacterial inhibition zones of $16.5 \mathrm{~mm}$ (welling method) are samples with $10 \%$ garlic extract concentration and glycerol plasticizer.
\end{abstract}

Keywords: Watermelon albedo, antimicrobial, edible film, garlic extract, plasticizer

\section{PENDAHULUAN}

Kerusakan bahan pangan dapat terjadi akibat degradasi kualitas makanan oleh mikroorganisme. Degradasi tersebut dapat dikurangi melalui pengemasan bahan pangan. Bahan kemasan yang banyak digunakan terbuat dari bahan yang tidak mudah terurai, seperti plastik.

Saat ini jumlah plastik yang digunakan sebagai bahan kemasan sudah mencapai $80 \%$ dari total penggunaan plastik (Sulchan dkk., 2007). Hal negatif dari penggunaan plastik adalah lamanya waktu penguraian antara $10-20$ tahun (Wahyuni, 2014). Upaya positif yang dapat dilakukan untuk mengurangi penggunaan plastik adalah meanfaatkan bahan pengganti kemasan makanan yang bersifat mudah terurai, seperti edible film. 
Edible film adalah lapisan tipis yang terbuat dari bahan layak konsumsi dan diaplikasikan sebagai pembungkus bahan pangan. Lapisan tersebut dapat menghambat perpindahan bahan terlarut, uap air, dan gas, serta melindungi dari kerusakan mekanis (Aceh \& Saleha, 2013). Lapisan tersebut umumnya terbuat dari polisakarida, protein, dan lemak. Salah satu senyawa polisakarida yang banyak digunakan untuk membuat edible film adalah pektin. Edible film berbahan dasar pektin memiliki permukaan yang halus namun kurang baik sifat mekaniknya. Sifat mekanik tersebut dapat diperbaiki melalui penambahan pati tapioca dan gliserol (Syarifuddin \& Yunianta 2015).

Salah satu sumber pektin yang belum banyak dimanfaatkan adalah limbah albedo semangka. Pada tahun 2014, Ditjen Hortikultura Kementerian Pertanian menyatakan bahwa produksi semangka mencapai 650.000 ton. Dari produksi tersebut, terdapat potensi limbah albedo semangka yaitu 36\% dari total berat semangka (Lembang, 2012).

Apabila dibandingkan dengan sumber lainnya, albedo semangka mengandung pektin relatif lebih banyak, yaitu sebesar 21,03\% (Lembang 2012). Karakteristik mekanik terbaik yang dimiliki oleh edible film albedo semangka adalah ketebalan 0,106 mm, perpanjangan (elongation) $32,4 \%$, kuat tarik (tensile strength) $2,68 \mathrm{kPa}$, kelarutan dalam air 89,39\%, dan laju penyerapan air (WTVR) 3,32 g. $\mathrm{mm} / \mathrm{m}^{2}$.jam (Anugrahati, 2001).

Sifat rapuh Edible film dapat diperbaiki dengan menambahkan pemlastis (plasticizer) ke dalam komposisi pembuatannya (Wirawan dkk., 2012). Pemlastis yang digunakan harus mampu mengurangi ikatan hidrogen pada ikatan intermolekuler, seperti gliserol dan sorbitol (Permadi dkk., 2008). Penggunaan sorbitol dapat memperbaiki karakteristik kuat tarik, laju penyerapan air, kelarutan dalam air, dan kecerahan, namun karakteristik kadar air, ketebalan, dan persen perpanjangan dapat diperbaiki melalui penggunaan gliserol (Zubaidah dkk., 2017).

Selain karakteristik mekaniknya, edible film sebagai pengemas bahan pangan perlu memiliki ketahanan terhadap kerusakan bahan pangan akibat keberadaan mikroorganisme. Oleh karena itu, dalam penelitian ini dilakukan pembuatan edible film dari pektin albedo semangka dengan penambahan sorbitol dan gliserol sebagai bahan pemlastis, tepung sagu sebagai tambahan sumber pektin, dan ekstrak bawang putih sebagai aditif antimikroba.

\section{METODE}

Penelitian ini dimulai dengan melakukan ekstraksi bawang putih (Rachmayanti 2015) dan ekstraksi pektin dari albedo semangka (Aslamiah, Melisa, and Wicakso 2014) yang telah dimodifikasi proses pengeringannya. Selanjutnya dilakukan pembuatan edible film (Syarifuddin \& Yunianta 2015) dengan variasi ekstrak bawang putih $(0 \%$; $2,5 \% ; 5 \% ; 7,5 \% ; 10 \%)$ dan jenis pemlastis (gliserol dan sorbitol). Pengeringan edible film dilakukan menggunakan oven.

Uji karakteristik produk yang dilakukan mencakup uji ketebalan, kuat tarik, elongasi, laju penyerapan air, dan daya hambat terhadap bakteri Escherichia coli.

Pengukuran tebal edible film dilakukan pada 5 titik yang berbeda menggunakan micrometer dengan kemurnian $0,001 \mathrm{~mm}$. Ketebalan film dipengaruhi oleh jumlah bahan yang tercampur di dalam larutannya. Untuk keperluan pengemasan, produk edible film dibuat setipis mungkin agar tidak mengganggu fisik produk yang dikemasnya. 
Pengujian kuat tarik dan perpanjangan dilakukan menggunakan alat Tarno Grocki. Nilai kuat tarik dihitung menggunakan persamaan (1)

Kuat tarik $=\frac{F}{A}$

dengan kuat tarik dalam satuan $\mathrm{N} / \mathrm{m}^{2}, \mathrm{~F}$ menunjukkan gaya maksimum yang diberikan hingga film rusak atau sobek $(\mathrm{N})$, dan A menunjukkan luas penampang film $\left(\mathrm{m}^{2}\right)$. Nilai persen perpanjangan dihitung menggunakan persamaan (2)

Persen perpanjangan $=$

$\frac{\text { panjang akhir-panjang awal }}{\text { panjang awal }} \times 100 \%$

Penentuan laju transmisi uap air dilakukan dengan bantuan silica gel (Syarifuddin \& Yunianta 2015). Laju tersebut dihitung menggunakan persamaan (3)

$$
\text { Laju transmisi uap air }=\frac{m}{A . t} \quad \ldots \text { (1) }
$$

dengan laju transmisi uap air dalam satuan $\mathrm{g} / \mathrm{m}^{2}$.jam, m menunjukkan massa uap air yang melewati bahan $(\mathrm{g}), \mathrm{t}$ menunjukkan waktu pengukuran (jam), dan A menunjukkan luas penampang sampel $\left(\mathrm{m}^{2}\right)$.

Pengujian daya hambat bakteri dilakukan dengan metode difusi sumuran, yaitu dengan cara melubangi medium yang telah diinokulasi bakteri hingga ukuran tertentu. Selanjutnya zat antibakteri dimasukkan ke dalam lubang tersebut. Selelah didiamkan beberapa lama maka akan terbentuk zona terang yang merupakan zona hambat dari aktifitas antibakteri

Hasil uji karakteristik edible film kemudian dibandingkan dengan Japanese Industrial Standard (JIS Z 1707, 1975) untuk edible film (Tabel 1).
Tabel 1. Standar karakteristik edible film (JIS Z1707, 1975)

\begin{tabular}{|c|l|c|}
\hline No & \multicolumn{1}{|c|}{ Karakteristik } & Nilai \\
\hline 1 & Kuat tarik $\left(\mathrm{kg}_{\mathrm{f}} / \mathrm{cm}^{2}\right)$ & $\geq 40$ \\
\hline 2 & Perpanjangan $(\%)$ & $\geq 70 \%$ \\
\hline 3 & Ketebalan $(\mathrm{mm})$ & $\leq 0,25$ \\
\hline 4 & $\begin{array}{l}\text { Laju transmisi uap air } \\
\left(\mathrm{g} / \mathrm{m}^{2} \text {.hari }\right)\end{array}$ & $\leq 10$ \\
\hline
\end{tabular}

\section{HASIL DAN PEMBAHASAN}

Hasil uji karakteristik edible film yang akan dibahas dalam tulisan ini adalah kuat tarik, persen perpanjangan, dan laju perpindahan uap air.

\section{Dampak Ekstrak Bawang Putih dan Jenis Pemlastis terhadap Kuat Tarik Edible film}

Uji kuat tarik dilakukan untuk mengetahui gaya maksimum yang dapat ditahan hingga film mengalami kerusakan (putus). Hasil pengujian ditunjukkan pada Gambar 1.

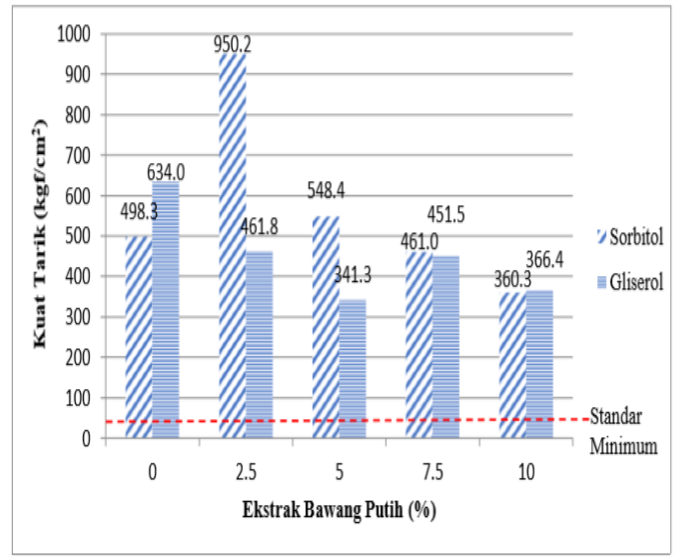

Gambar 1. Dampak Ekstrak Bawang Putih dan Jenis Pemlastis terhadap Kuat Tarik Edible film

Gambar 1 menunjukkan bahwa ekstrak bawang putih dapat menyebabkan pelemahan ikatan hidrogen pada matrik intermolekuler dan terputusnya ikatan amilosa (Sari dkk., 2013) sehingga menyebabkan penurunan kuat tarik edible film. Putusnya ikatan amilosa menyebabkan kerusakan pada jaringan gel edible film. Penggunaan pemlastis sorbitol memberikan 
karakteristik kuat tarik yang lebih baik dari gliserol. Hal ini terjadi karena gliserol memiliki kemampuan mengikat air yang lebih baik dibandingkan sorbitol. Kemampuan mengikat air yang rendah menyebabkan rendahnya kemampuan sorbitol untuk melemahkan ikatan hidrogen (Taufik \& Fatma, 2014).

Di sisi lain, penambahan sorbitol menyebabkan peningkatan karakteristik kuat tarik edible film (Sari dkk., 2013), yaitu antara 341 s.d. $950 \quad \mathrm{~kg}_{\mathrm{f}} / \mathrm{cm}^{2}$. Karakteristik ini telah memenuhi standar JIS $\left(\geq 40 \quad \mathrm{~kg}_{f} / \mathrm{cm}^{2}\right)$. Pada rentang penambahan ekstrak bawang putih 0 $10 \%$, produk edible film yang memiliki kuat tarik terbaik diperoleh pada sampel yang ditambahkan ekstrak bawang putih 2,5\% dan sorbitol sebagai pemlastis.

Edible film yang memiliki kuat tarik tinggi akan lebih kuat menahan beban produk yang dikemasnya, sedangkan edible film yang memiliki kuat tarik rendah bersifat lebih rapuh.

\section{Dampak Ekstrak Bawang Putih dan Jenis Pemlastis terhadap Perpanjangan Edible Film}

Uji persen perpanjangan dilakukan untuk mengetahui maksimum perubahan panjang bahan sebelum bahan tersebut mengalami kerusakan (sobek). Hasil pengujian ditunjukkan pada Gambar 2 .

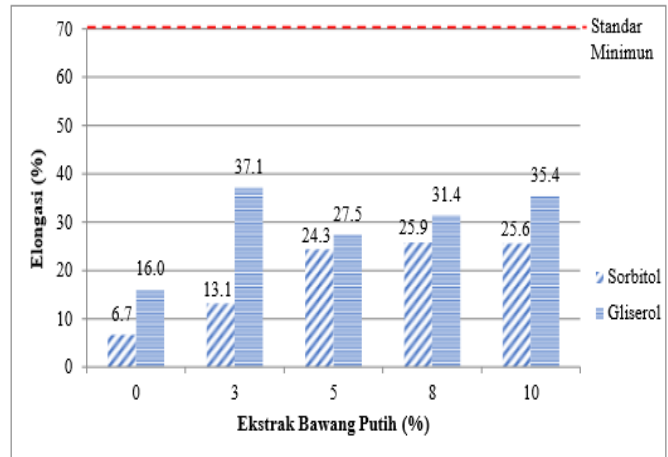

Gambar 2. Dampak Ekstrak Bawang Putih dan Jenis Pemlastis terhadap Perpanjangan Edible film
Gambar 2 menunjukkan bahwa ekstrak bawang putih dapat mengurangi gaya intermolekuler amilosa yang berakibat pada meningkatnya jarak antar molekul amilosa dan meningkatan perpanjangan edible film (edible film semakin elastis).

Penambahan gliserol menyebabkan edible film lebih elastis karena gliserol dapat meningkatkan fleksibilitas film (N. Sari et al. 2013). Karakteristik perpanjangan edible film berada pada rentang $6-40 \%$, sehingga belum memenuhi standar JIS $(\geq 70 \%)$. Pada rentang penambahan ekstrak bawang putih $0-10 \%$, produk edible film dengan karakteristik persen perpanjangan terbaik diperoleh pada penambahan ekstrak bawang putih $10 \%$ dengan pemlastis gliserol.

\section{Sifat Antibakteri Edible film}

Bawang putih mengandung senyawa allicin yang memiliki kemampuan menghambat aktivitas bakteri. Efektivitas anti bakteri pada edible film yang ditambahkan sorbitol tidak dapat terukur, namun hasil pengujian pada edible film yang ditambahkan gliserol diberikan pada Gambar 3.

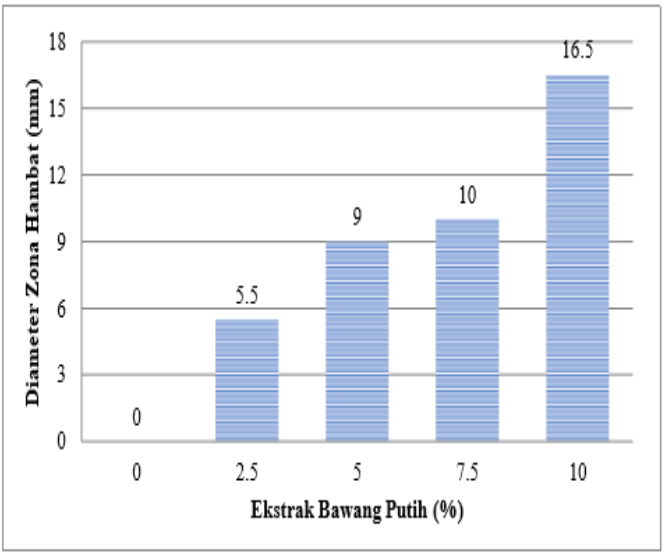

Gambar 3. Grafik Uji Bakteri Metode Sumuran

Gambar 3 menunjukkan bahwa peningkatan ekstrak bawang putih menyebabkan peningkatan diameter zona 
hambat. Diameter zona hambat yang besar menunjukkan daya hambat bakteri yang semakin baik. Pada rentang penambahan ekstrak bawang putih $0-$ $10 \%$, edible film yang dapat meningkatkan daya tahan bahan pangan terhadap kontaminasi bakteri paling baik adalah bahan yang ditambahkan ekstrak bawang putih $10 \%$.

\section{SIMPULAN}

1. Penambahan sorbitol menyebabkan peningkatan karakteristik kuat tarik edible film, yaitu antara 341-950 $\mathrm{kgf} / \mathrm{cm}^{2}$, sudah memenuhi standar JIS ( $\left.\geq 40 \mathrm{kgf} / \mathrm{cm}^{2}\right)$.

2. Penambahan gliserol menyebabkan edible film lebih elastis, dengan persen perpanjangan berada pada rentang 6 - 40\%, sehingga belum memenuhi standar JIS ( $\geq 70 \%)$.

3. Peningkatan ekstrak bawang putih menyebabkan daya hambat bakteri semakin baik.

4. Produk edible film dengan karakteristik terbaik (kuat tarik 366,4 $\mathrm{kg}_{f} / \mathrm{cm}^{2}$ dan perpanjangan $35,4 \%$ ) diperoleh pada penambahan pemlastis gliserol dan ekstrak bawang putih $10 \%$.

\section{DAFTAR RUJUKAN}

Aceh, B. \& Saleha, S., 2013. Preparation and Characterization Edible film Packaging from Carrageenan. Proceedings of The 3rd Annual International Conference Syiah Kuala University (AIC Unsyiah), 3(3): 44-50

Anugrahati, N. 2001. Karakterisasi Edible film Komposit Pektin Albedo Semangka (Citrullus Vulgaris Schard.) dan Tapioka. Yogyakarta: Universitas Gadjah Mada.

Aslamiah, Melisa, T. M.; \& Wicakso, D. R., 2014. Pengambilan Pektin dari Albedo Semangka dengan Proses Ekstraksi Asam. Konversi.
Lembang, E. 2012. Variasi Waktu dan Suhu Ekstraksi Albedo Semangka (Citrullus Vulgasris Schard) Terhadap Kualitas Permen Jelly. Yogyakarta: Universitas Atma Jaya Yogyakarta.

Permadi, F.; Sari, T.I.; \& Manurung, H. P., 2008. Pembuatan Edible film dari Kolang Kaling. Jurnal Teknik Kimia 4 (15).

Rachmayanti, P. W. 2015. Karakterisasi Antimicrobial Film dari Kedelai Dan Tapioka Sebagai Pengemas Makanan. Semarang: Universitas Negeri Semarang.

Sari, N.; Murni, S.W.; Pawignyo, H.; \& Widyawati, D. 2013. Pembuatan Edible film dari Tepung Jagung (Zea mays L.) dan Kitosan. Yogyakarta: UPN 'Veteran" Yogyakarta.

Sari, R. P.; Wulandari, S. T.; \& Wardhani, D. H., 2013. Pengaruh Penambahan Ekstrak Bawang Putih (Allium Sativum) terhadap Karakteristik Edible film Pati Ganyong (Canna Edulis Kerr.). Jurnal Teknologi Kimia dan Industri, 2(3): 82-87.

Sulchan, M. \& Wahyuni, E.N., 2007. Keamanan Pangan Kemasan Plastik Sterefoam. Kedokteran Indonesia 57: 54-59.

Syarifuddin; Ahmad; \& Yunianta, 2015. Characterization of Edible film from Grapefruit Albedo Pectin and Arrowroot Starch. Jurnal Pangan dan Agroindustri 3(4): 1538-1547.

Taufik, M. \& Fatma. 2014. Karakteristik Edible film Berbahan Dasar Gelatin Kulit Kaki Broiler. Makassar: Universitas Hasanuddin.

Wahyuni, T. 2014. Jenis Sampah dan Lama Proses Penghancurannya.

Wirawan, S. K.; Prasetya, A.; \& Ernie E., 2012. Pengaruh Plasticizer pada Karakteristik edible film dari pektin. Reaktor 14: 61-67. 
Zubaidah, E.; Sitompul, A. J.; \& Sitompul, S., 2017. Pengaruh Jenis Dan Konsentrasi Plastisizer Terhadap Sifat Fisik Edible film Kolang Kaling (Arenga pinata). Jurnal Pangan dan Agroindustri 5: 13-25 